\title{
Buffalograss Seedling Tolerance to Postemergence Herbicides
}

\author{
Jack D. Fry and Ward S. Upham \\ Department of Horticulture, Forestry, and Recreation Resources, Kansas \\ State University, Manhattan, KS 66506
}

Additional index words. Buchloe dactyloides, weed control

\begin{abstract}
In 1992 and 1993, 12 postemergence herbicide treatments were applied to fieldgrown buffalograss [Buchloe dactyloides (Nutt.) Engelm.] seedlings having 1 to 3 leaves and 2 to 4 tillers, respectively. The only herbicide treatments that did not cause plant injury at 1 or 2 weeks after treatment (WAT) or reduce turf coverage 4 or 6 WAT compared to nontreated plots (in 1992 or 1993 ) were (in $\mathrm{kg} \mathrm{ha}^{-1}$ ) 0.6 dithiopyr, 0.8 quinclorac, 2.2 MSMA, and 0.8 clorpyralid. Evaluated only in 1993 , metsulfuron methyl $\left(0.04 \mathrm{~kg}^{-h a^{-1}}\right)$ also caused no plant injury or reduction in coverage. Fenoxaprop-ethyl $\left(0.2 \mathrm{~kg}^{-h a^{-1}}\right)$ caused severe plant injury and reduced coverage by $>95 \%$ at 6 WAT. Dicamba reduced coverage by $11 \%$ at 6 WAT in 1992 but not 1993. The chemicals (in kg.ha-1) triclopyr (0.6), 2,4-D (0.8), triclopyr (1.1) + 2,4-D (2.8), 2,4-D (3.1) + triclopyr $(0.3)+$ clorpyralid $(0.2)$, and 2,4D (2.0) + mecoprop (1.1) + dicamba (0.2) caused plant injury at 1 or 2 WAT in 1992 or 1993, but coverage was similar to that of nontreated turf by 6 WAT. Chemical names used: 3,6dichloro-2-pyridinecarboxylic acid (clorpyralid); 3,6-dichloro-o-anisic acid (dicamba); (+/-)-2-[4-(2,4-dichlorophenoxy)phenoxy]propanoic acid (diclofop); 3,5pyridinedicarbothioic acid, 2-(difluoromethyl)-4-(2-methylpropyl)-6-(trifluoromethyl)$S, S$-dimethyl ester (dithiopyr); 2-[4-[(6-chloro-2-benzoxazolyl)oxy]phenoxy] propanoate (fenoxaprop-ethyl); 2-(2,4-dichlorophenoxy)propionic acid (mecoprop); methyl 2-[[][(4methoxy-6-methyl-1,3,5-triazin-2-yl)-amino]carbonyl]amino]sulfonyl]benzoate (metsulfuron methyl); monosodium salt of methylarsonic acid (MSMA); 3,7-dichloro-8quinolinecarboxylic acid (quinclorac); [(3,5,6-trichloro-2-pyridinyl)oxy] acetic acid (triclopyr); (2,4-dichlorophenoxy) acetic acid (2,4-D).
\end{abstract}

Buffalograss is a stoloniferous, warmseason grass native to the Great Plains of the United States. It is used as a low-maintenance turf for parks, golf course roughs, home lawns, and roadsides (Feucht and Butler, 1988). In Kansas, 7 to 9 weeks are required for buffalograss stand establishment if seeding is performed between May and July (Fry et al., 1993). Identification of an herbicide that could be used during establishment would be valuable for professional turf managers.

To our knowledge, no data are available on buffalograss seedling tolerance to postemergence herbicides. However, limited work has been performed with mature turf. Butler et al. (1985) found that the broadleaf herbicides 2,4$\mathrm{D}$ and dicamba (applied at 1.1 to 4.5 and 0.6 to $4.5 \mathrm{~kg} \cdot \mathrm{ha}^{-1}$, respectively) reduced turf quality for $\leq 40$ days after application. McCarty and Colvin (1992) evaluated 15 postemergence herbicides on mature '609' and 'Prairie' buffalograss in Florida and indicated that all broa-

\footnotetext{
Received for publication 3 Mar. 1994. Accepted for publication 24 May 1994. Kansas Agricultural Expt. Station contribution no. 94-395-J. We thank Kevin Kamphaus for technical assistance. This research was supported in part by grants from the Kansas Turfgrass Foundation and Kansas Golf Course Superintendent's Association. The cost of publishing this paper was defrayed in part by the payment of page charges. Under postal regulations, this paper therefore must be hereby marked advertisement solely to indicate this fact.
}

dleaf weed herbicides significantly reduced turf quality for 20 to 30 days after treatment. Of the herbicides evaluated for grass weed control, metsulfuron methyl, quinclorac , and diclofop $\left(0.56,0.017\right.$, and $1.12 \mathrm{~kg} \cdot \mathrm{ha}^{-1}$, respectively) did not reduce turf quality below an acceptable level.

Our objective was to evaluate broadleaf and grass postemergence herbicides commonly used in turf for effects on buffalograss seedlings and stand establishment.

\section{Materials and Methods}

Field studies were conducted during 1992 and 1993 at the Rocky Ford Turfgrass Research Center, Manhattan, Kan. Soil was a Chase silt loam (fine, montmorillonitic, mesic, Aquic Arquidolls) with a $6.5 \mathrm{pH}$. Soil samples, taken at a 0 - to $10-\mathrm{cm}$ depth in 1992, revealed that soil $\mathrm{P}$ and $\mathrm{K}$ were at 200 and $907 \mathrm{~kg} \cdot \mathrm{ha}^{-1}$, respectively. A $10 \mathrm{~N}-7.8 \mathrm{P}-18.3 \mathrm{~K}$ fertilizer was incorporated at $25 \mathrm{~kg} \mathrm{~N} /$ ha before planting. On 2 July 1992 and 27 July 1993, 'Sharp's Improved' buffalograss burs were seeded at 49 $\mathrm{kg} \cdot \mathrm{ha}^{-1}$ using a drop spreader. Herbicides (Table 1) were applied on 28 July 1992 and 16 Aug. 1993 with a $\mathrm{CO}_{2}$-powered backpack sprayer calibrated to deliver 561 liters.ha ${ }^{-1}$ at $241 \mathrm{kPa}$. At the time of application, buffalograss had 1 to 3 leaves in 1992 and 2 to 4 tillers in 1993. At the time of this study, none of the herbicides evaluated was labeled for seedling buffalograss. Dithiopyr and 2,4-D are labeled for use on mature buffalograss. When rainfall was not adequate, irrigation was used to provide $\approx 25 \mathrm{~mm}$ of water weekly. Air temperatures at the hour of application were 21 and $32 \mathrm{C}$ in 1992 and 1993, respectively.

Data were collected on buffalograss plant injury and coverage. Plant injury was defined as chlorosis or necrosis of leaf blades or leaf sheaths relative to nontreated plants and was rated on a scale of $0 \%$ to $100 \%(0 \%=$ no chlorosis or necrosis visible in the plot and $100 \%=$ all plants in the plot dead) at 1 and 2 WAT. Buffalograss coverage was rated visually at 4 and 6 WAT using a $0 \%$ to $100 \%$ scale, where $0 \%=$ bare ground and $100 \%=$ complete coverage.

Herbicide treatments were applied to $1 \times 2$ $\mathrm{m}$-plots arranged in a randomized completeblock design with three replicates. Means were separated using the Waller-Duncan Bayesian $\mathrm{k}$ ratio $t$ test $(\mathrm{k}=100 ; P=0.05)$.

\section{Results and Discussion}

At 1 WAT in 1992, when treated with fenoxaprop-ethyl, triclopyr + 2,4-D, 2,4-D + mecoprop + dicamba, or dicamba, $31 \%$ to $43 \%$ of plot areas were injured while the controls remained unchanged (Table 1). By 2 WAT, turf treated with the herbicides noted and triclopyr alone showed significantly more plant injury than nontreated turf.

Plots treated with fenoxaprop-ethyl had $61 \%$ less coverage than nontreated turf at 4 WAT, and $91 \%$ less coverage at 6 WAT in 1992. Dicamba-treated seedlings produced $25 \%$ less coverage than nontreated seedlings at 4 WAT and $11 \%$ less at 6 WAT (Table 1).

Less plant injury occurred at 1 and 2 WAT in 1993 than in 1992 (Table 1). At 1 WAT, fenoxaprop-ethyl, triclopyr $+2,4-\mathrm{D}$, and dicamba caused significant plant injury. By 2 WAT, $80 \%$ of the plot areas treated with fenoxaprop-ethyl were injured, and $10 \%$ of those treated with triclopyr $+2,4-\mathrm{D}$ were injured. Plants had not tillered in 1992, but had 2 to 4 tillers in 1993. Apparently, plants that have tillered by the time of application are more herbicide-tolerant than those that have not. At 4 WAT in 1993, buffalograss coverage was $13 \%$ to $83 \%$ lower in plots where seedlings had been treated with fenoxaprop-ethyl, triclopyr $+2,4-\mathrm{D}$, triclopyr $+2,4-\mathrm{D}+$ clorpyralid, 2,4-D + mecoprop + dicamba, dicamba, or 2,4-D (Table 1). By 6 WAT, only turf treated with fenoxaprop-ethyl exhibited coverage lower than nontreated turf.

Broadleaf herbicides, clorpyralid in both years, and metsulfuron methyl in 1993, caused no visible plant injury at 1 or 2 WAT, or reduced coverage 4 or 6 WAT. McCarty and Colvin (1992) also observed that mature buffalograss had acceptable tolerance to metsulfuron methyl $\left(0.017 \mathrm{~kg} \cdot \mathrm{ha}^{-1}\right)$. Other broadleaf herbicides caused some degree of plant injury at 1 or 2 WAT in 1992 and 1993. In most cases, turf recovered from the injury and exhibited coverage similar to turf in nontreated plots by 6 WAT. In 1992, dicamba was the only broadleaf herbicide treatment that resulted in lower buffalograss coverage compared to nontreated turf 6 WAT. McCarty and 
Colvin (1992) showed that (in kg.ha-1) 0.56 triclopyr, 1.12 2,4-D, 0.56 dicamba, and 1.12 2,4-D + 0.54 dicamba +0.13 mecoprop caused unacceptable plant injury to mature buffalograss $\leq 20$ days after treatment in Florida.

The grass herbicides (dithiopyr, quinclorac, and MSMA) also caused no plant injury or reduction in coverage. Dithiopyr is considered a preemergence herbicide, but it has postemergence activity on crabgrass (Digitaria spp.) when applied shortly after emergence. Quinclorac is not labeled yet for use on turf,

Table 1. Plant injury and percent coverage after treatment of buffalograss seedlings with postemergence herbicides in field studies (Manhattan, Kan.).

\begin{tabular}{|c|c|c|c|c|c|c|c|c|c|}
\hline \multirow[b]{3}{*}{ Herbicide } & \multirow{3}{*}{$\begin{array}{c}\text { Rate } \\
\left(\mathrm{kg} \cdot \mathrm{ha}^{-1}\right)\end{array}$} & \multicolumn{4}{|c|}{$1992^{z}$} & \multicolumn{4}{|c|}{1993} \\
\hline & & \multicolumn{2}{|c|}{ Plant injury $(\%)^{y}$} & \multicolumn{2}{|c|}{ Coverage $(\%)^{\mathrm{x}}$} & \multicolumn{2}{|c|}{ Plant injury (\%) } & \multicolumn{2}{|c|}{ Coverage $(\%)$} \\
\hline & & $1 \mathrm{WAT}^{\mathrm{w}}$ & $2 \mathrm{WAT}$ & $4 \mathrm{WAT}$ & $6 \mathrm{WAT}$ & $1 \mathrm{WAT}$ & $2 \mathrm{WAT}$ & $4 \mathrm{WAT}$ & $6 \mathrm{WAT}$ \\
\hline Nontreated & --- & 0 & 0 & 65 & 96 & 0 & 0 & 83 & 95 \\
\hline Dithiopyr & 0.6 & 0 & 0 & 73 & 95 & 0 & 0 & 88 & 98 \\
\hline Fenoxaprop-ethyl & 0.2 & 31 & 70 & 4 & 5 & 67 & 80 & 0 & 0 \\
\hline Quinclorac & 0.8 & 0 & 0 & 88 & 100 & 0 & 0 & 92 & 100 \\
\hline MSMA & 2.2 & 0 & 0 & 78 & 94 & 3 & 0 & 93 & 100 \\
\hline Triclopyr & 0.6 & 0 & 30 & 88 & 100 & 3 & 0 & 80 & 94 \\
\hline Clorpyralid & 0.8 & 16 & 0 & 78 & 97 & 0 & 0 & 85 & 96 \\
\hline Triclopyr & 1.1 & & & & & & & & \\
\hline$+2,4-\mathrm{D}$ & 2.8 & 34 & 30 & 72 & 98 & 10 & 10 & 60 & 93 \\
\hline $2,4-\mathrm{D}$ & 3.1 & & & & & & & & \\
\hline + triclopyr & 0.3 & & & & & & & & \\
\hline + clorpyralid & 0.2 & 8 & 13 & 77 & 100 & 0 & 0 & 70 & 98 \\
\hline $2,4-\mathrm{D}$ & 2.0 & & & & & & & & \\
\hline+ mecoprop & 1.1 & & & & & & & & \\
\hline+ dicamba & 0.2 & 34 & 27 & 77 & 97 & 0 & 3 & 65 & 97 \\
\hline Dicamba & 0.8 & 43 & 47 & 40 & 85 & 7 & 3 & 72 & 97 \\
\hline $2,4-\mathrm{D}$ & 0.8 & 0 & 0 & 83 & 97 & 0 & 3 & 72 & 96 \\
\hline $\begin{array}{l}\text { Metsulfuron } \\
\text { methylv }^{v}\end{array}$ & 0.04 & --- & --- & --- & --- & 0 & 0 & 86 & 100 \\
\hline $\operatorname{MSD}_{(0.05)}$ & --- & 22 & 14 & 21 & 5 & 6 & 5 & 10 & 5 \\
\hline
\end{tabular}

${ }^{\text {z}}$ Seedlings had 1 to 3 leaves in 1992 and 2 to 4 tillers in 1993.

y Plant injury was rated visually on a $0 \%$ to $100 \%$ scale, where $0 \%=$ no chlorosis or necrosis and $100 \%=$ dead plants.

${ }^{\mathrm{x}}$ Coverage was rated visually on a $0 \%$ to $100 \%$ scale, where $0 \%=$ bare ground and $100 \%=$ complete coverage.

${ }^{\mathrm{w}} \mathrm{WAT}=$ weeks after treatment.

${ }^{v}$ Metsulfuron methyl was evaluated only in 1993.

but has provided $>95 \%$ control of crabgrass in experiments in Kansas (Upham et al., 1993). Mature buffalograss has exhibited acceptable tolerance to quinclorac $\left(0.56 \mathrm{~kg} \cdot \mathrm{ha}^{-1}\right)$, and only slight injury after treatment with MSMA $\left(2.24 \mathrm{~kg} \cdot \mathrm{ha}^{-1}\right)$ in Florida (McCarty and Colvin, 1992).

Our studies indicate that selected grassy and broadleaf postemergence herbicides cause minimal or no plant injury to seedling buffalograss. Tillered seedlings apparently were more tolerant of herbicide treatments; hence, delaying application until tillering has occurred seems prudent. Approval of herbicides deemed safe for use on seedling buffalograss would assist turf managers during turf establishment.

\section{Literature Cited}

Butler, J.D., D.D. Minner, and J.D. Fry. 1985. Weed control in buffalograss [Buchloe dactyloides (Nutt.) Engelm.], p. 114. In: Agronomy abstracts. Amer. Soc. Agron., Madison, Wis.

Feucht, J.R. and J.D. Butler. 1988. Landscape Management. Van Nostrand and Reinhold, New York.

Fry, J., W. Upham, and L. Leuthold. 1993. Planting month and seed soaking affect buffalograss establishment. HortScience 28:902-903.

McCarty, L.B. and D.L. Colvin. 1992. Buffalograss tolerance to postemergence herbicides. HortScience 27:898-899.

Upham, W.S., J.D. Fry, and K. Kamphaus. 1993. Control of crabgrass and dandelion in Kentucky bluegrass with selected postemergence herbicides. 1993 Turfgrass research. Rpt. Progress 685, Kansas Agr. Expt. Sta., Kansas State Univ., Manhattan. 